\title{
Climate Variability and Associated Response of Larix griffithii in Kanchenjunga Conservation Area of Nepal
}

\author{
Sijar Bhatta ${ }^{1}$, Man Kumar Dhamala ${ }^{1,2}$, Prakash Chandra Aryal ${ }^{1}$, Raju Chauhan ${ }^{3}$, Binod Dawadi ${ }^{4,5, *}$ \\ ${ }^{1}$ Department of Environmental Science, Goldengate International College, Kathmandu, Nepal \\ ${ }^{2}$ Central Department of Environmental Sciences, Tribhuvan University \\ ${ }^{3}$ Department of Environmental Science, Amrit Campus, Kathmandu, Nepal \\ ${ }^{4}$ Central Department of Hydrology and Meteorology, Tribhuvan University, Kirtipur, Nepal \\ ${ }^{5}$ Kathmandu Center for Research and Education Chinese Academy of Sciences - Tribhuvan University, Kathmandu Nepal \\ *Corresponding author: dawadibinod@gmail.com
}

\begin{abstract}
Mountains are most sensitive to climate change and the impacts are already evident in different sphere and sector of mountain regions, especially in the vulnerable countries like Nepal. This research was designed to integrate hydro-climatic data analysis and climate sensitivity through dendrochronology to generate an understanding on how Larix griffithii, one of the least studied conifers in Nepal, is responding to climate variability and change. A significant warming trend of $0.021^{\circ} \mathrm{C}$ year ${ }^{-1}$ was observed in the region. Precipitation was more erratic without any significant increasing, decreasing or cyclic trend. Between 1962 and 2012, the warmest year on record was 2010 while 1997 was the coolest year on record. After 1997 a clear shift in temperature regime was observed with the recent decade experiencing a sharp increase in temperature. A site chronology extending 17452015 AD was prepared. Very strong significant correlation was observed between the standard chronology and monthly temperature especially in summer months indicating a potential for summer months' temperature reconstruction. The reconstructed summer month's temperature data for the period 1770-2015 captured 34\% variability. The short cold episodes were observed around the 1810s, 1910s, and 1970s while warm periods were observed around 1890s, 1920s and 2000s. Radial growth of Larix griffithii in the site shows a highly significant negative relationship with the monthly temperature of the previous year and current year summer months especially for June, July, August, September of previous year and July, August and September of the current year. Significant positive correlation was observed for both previous year and current year July precipitation. The summer temperature coupled with precipitation is seen to limit the tree growth through moisture limitations. With the temperature in increasing trend, it is likely that the growth of Larix will face more heat stress in future, making them more dynamic to the changing climate.
\end{abstract}

Keywords: climate variability, Nepal Himalaya, growth-climate response, climate reconstruction, dendrochronology

Cite This Article: Sijar Bhatta, Man Kumar Dhamala, Prakash Chandra Aryal, Raju Chauhan and Binod Dawadi, "Climate Variability and Associated Response of Larix griffithii in Kanchenjunga Conservation Area of Nepal.” Applied Ecology and Environmental Sciences, vol. 6, no. 1 (2018): 23-30. doi: 10.12691/aees-6-1-4.

\section{Introduction}

Climate in Nepal has changed significantly over the last few decades. Temperature increase has been observed since the 1970s, where the increase in temperature is even more pronounced in higher elevations [1]. Over the same interval, precipitation has become both more intense and erratic, with the region experiencing fewer rainy days on average [2,3]. The observed changes in the climate have a huge impact on various sectors such as agriculture, biodiversity, disaster, water and energy, human health, infrastructures and settlements [4]. In many areas food production has declined as a result of climate change, posing a threat to food security [5] while other communities are at high risk from climate induced disasters, mainly flooding and inundation in Terai and landslide in the hills [6]. The incidence of flooding and landslides are followed by epidemics in most of the cases. Range shifting is a common response to climate change in high altitude plants and animals as a result of which mountain communities are facing difficulties in livestock rearing and food production. Climate change is having a direct impact on forest affecting the productivity of forest species [7] through direct effects on tree demography and indirect effects on disturbance regimes $[8,9]$. Unfavorable climatic conditions, such as low temperatures or drought, may govern the limits of species' ranges and any change in environmental conditions can lead to significant changes in a species' demographic patterns. In mountain regions, climate change in the form of warming may lead to an upward movement of the tree line and the upper altitudinal limit for particular species [10].

Larix sp. is the least studied species in the context of Nepal. It is mainly because these species are confined to 
the eastern Himalayas, especially south and east [11] and distribution of some species appears to have a very restricted range being recorded from only two localities one in Tibet and another in Nepal [12]. Understanding past climate variation and its effects on forests help us to anticipate the potential effects of global warming. Age and diameter distributions are powerful tools for assessing changes in forest structure and composition over time [13]. Montane species like Larix sp. contain a distinct signature of climate, especially temperature and precipitation. Response to any variability of climate is marked in the rings of such species. Thus, use of dendrochronological technique applied to the Larix sp in the eastern Himalaya of Nepal gives a possibility to obtain retrospective patterns of climate change. This will help to identify how montane species have been responding to the impact of climate variability and change. Understanding the impact of climate on the quality of forest will help in the management of forest in future. This study aims to assess climate variability in Kanchenjunga Conservation Area of Nepal and study the growth response of Larix griffithii to climate variability.

\section{Materials and Methods}

\subsection{Study Area}

This study was carried out in the upper part of Ghunsa valley of Taplejung district in eastern Nepal. This area lies within Kanchenjunga Conservation Area (KCA). This valley is characterized by upper temperate and subalpine climatic conditions and is mainly composed of conifers like Larix species, Abies spectabilis and some broadleaf species like Betula utilis. At higher elevations near Ghunsa Village (3300 to 3400 masl), Abies spectabilis replaces Tsuga dumosa on stable slopes and old moraines to form a subalpine forest formation, while Larix griffithii forms pure stands on the depositional terraces, loose slopes and other places prone to a higher rate of disturbance [14]. Larix forests of the Kanchenjunga region are ecologically significant because they represent the westernmost extreme for this unique, deciduous conifer of the Eastern Himalaya. Larix is fairly common from the Sikkim to SW China and rare in the Langtang region, but Kanchenjunga supports the only extensive, pure stands found in Nepal.

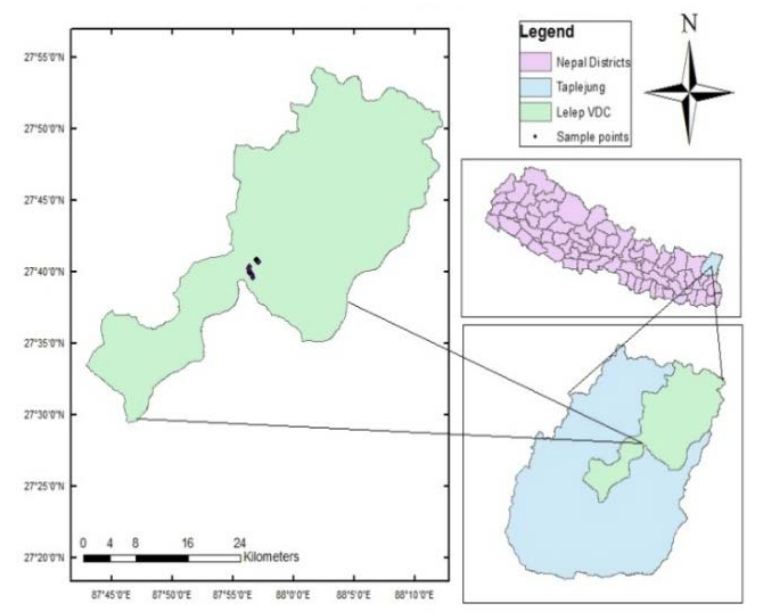

Figure 1. Study site

\subsection{Field visit and Data Collection}

Vegetation survey was done in the sites in belt transects along altitude whenever possible. Along the transects, each alternative quadrats of size of $20 \times 20 \mathrm{~m}^{2}$ were laid at an interval of $20 \mathrm{~m}$ and the Larix sp were surveyed within the belt for height and $\mathrm{DBH}$ of trees, and sapling and seedling counts. The random approach was used for tree core collection. Whenever a Larix tree was encountered, the latitude, longitude and elevation using Geographic Positioning System (GPS) were recorded. In addition, other environmental features such as distance from water sources, anthropogenic disturbances (e.g. grazing, trampling, and tree felling) and associated species were also collected. Tree cores were collected using an increment borer following the commonly used technique [15]. The cores of Larix sp. were collected from breast height $(1.3 \mathrm{~m})$. One to two cores per tree were collected. A total of 56 cores were collected from 28 Larix trees in the study site. Collected cores were put in the plastic straw pipe with proper labelling. Then, the collected core samples were brought to the Dendro-lab of Nepal Academy of Science and Technology (NAST) for laboratory analysis. The presence points of the trees were arranged in excel and checked for inaccuracies. Data of tree cores and chronology were managed in spreadsheet along with temperature and precipitation data for cross dating after finding suitable months and season for the chronology.

\subsection{Climate Data Collection and Analysis}

Precipitation and temperature data for Taplejung station were collected from DHM. The monthly temperature data were available for the period 1962 to 2012 A.D, while the monthly precipitation data were available for the period 1948 to 2013. For both climate variables, data were available for the period of more than 30 years, therefore increasing the accuracy of climate analysis. Frequency distribution graphs were plotted for both temperature and precipitation data. Time series analysis was done to estimate trend for average annual temperature and annual precipitation data by running 11 years average to visualize the decadal variability and running 31 years average to determine the bandwidth of climate change [16]. Leastsquares linear regression was also used to evaluate increasing or decreasing slope of trends. To study the long term climate variability, summer temperature was reconstructed using the procedure given in section c below. The significance of the trend of each series was determined by conducting Man Kendall test for trend analysis in R. The normal values of precipitation and air temperature based parameters are calculated following WMO climate guidelines [17].

\subsection{Tree Core Sample Processing, Chronology Development and Reconstruction}

Collected core samples were prepared and analyzed using standard dendrochronological techniques (Fritts, 1976). After drying, mounting, sanding and polishing the samples, each ring was assigned a calendar year with the help of known date of formation of the outer ring, 
observing under the stereo zoom microscope. The width of each ring was measured to the nearest $0.01 \mathrm{~mm}$ precision with the LINTAB ${ }^{\text {TM5 }}$ measuring system attached to a PC with the TSAP-Win software package [18]. Each tree ring width series was visually (looking the math graphs) and statistically cross dated (looking Gleichläufigkeit, t-values and the cross-date index-CDI) using the software package TSAP-Win [19]. The accuracy of crossdating and measurements were further checked using the COFECHA program [20,21]. The ring-width data were standardized using the computer program ARSTAN [22] to remove geometric and ecological growth trends resulting from tree-to-tree competition and stand dynamics while preserving variations that are likely related to climate [23]. The ring-width series were standardized using conventional detrending methods using a spline of 32 yrs. or $67 \%$ length with a $50 \%$ frequency response cutoff was used [24], three chronologies namely standard, residual and arstan were prepared using the corrected sample. Various chronology statistics like mean sensitivity, standard deviation, autocorrelation, within tree correlation, between tree correlation, mean series correlation, signal-to-noise ratio (SNR), expressed population signal (EPS) and variance explained were calculated to assess the quality of the site chronologies. Chronology quality was estimated using rbar [25] and expressed population signal statistics [26]. Field observation and tree ring data show that radial growth of Larix in current study sites ceases in September-October. Because climate in the preceding growing season often influences tree growth in the following year [27], the influence of temperature and precipitation from June of the previous growth year to October of current growth year were analyzed. Pearson's correlation coefficient was used to quantify relationships between tree-ring chronologies and climate variables, i.e. monthly average $\left(\mathrm{T}_{\text {mean }}\right)$, and total monthly precipitation.

The significant correlations obtained between the ring width chronology and the climatic variables were used to develop the transfer function to reconstruct the past climate [15]. A simple linear regression model was used to relate tree-ring width against seasonal climate, and tested the time-stability of that model by using Split-sample-half or leave-one-out cross-validation technique depending upon the length of available climatic data. Estimated and observed climate data were subjected to F-test of significance in order to examine the reliability of the relationship between the response variable and the set of the predictor variables. Statistics like sign test, reduction of error (RE), and product means test (PMT) were computed for verification of the transfer function. Positive values of RE and CE of climate-growth models were taken as the basis for validity and reliability of regression model [28]. Once the model was judged effective and stable, it was applied to reconstruct past climate for the period covered by tree-ring width chronology. The reconstruction was truncated at the point in which EPS value becomes less than the threshold value of 0.85 and the tree-ring chronology was unduly influenced by non-climatic noise [26]. A climate reconstruction of the summer season (JJAS) in KCA was attempted by using the ring width chronology of Larix.

\section{Results}

\subsection{Climate Variability in KCA}

The temperature in the study area ranged from $3.5^{\circ} \mathrm{C}$ in January to $22.5^{\circ} \mathrm{C}$ in the month of July. The normal temperature for KCA recorded at the Taplejung station was found to be $16.15^{\circ} \mathrm{C}$. The inter-annual variation of Average Annual temperature (AAT) can be clearly observed with increasing variability in recent years (Figure 2). Between 1960 and 2012, AAT was found to fluctuate a maximum of $1.47^{\circ} \mathrm{C}$ above the normal temperature in the year 2010 and a maximum $0.72^{\circ} \mathrm{C}$ below the normal temperature in the year 1997 indicating that within this time period, 2010 was the warmest year and 1997 was the coolest year. The time series of AAT shows an increasing trend of temperature (Figure 3 a.). A statistically significant warming trend of $0.021^{\circ} \mathrm{C}$ year ${ }^{-1}$ was observed $(p<0.001)$.

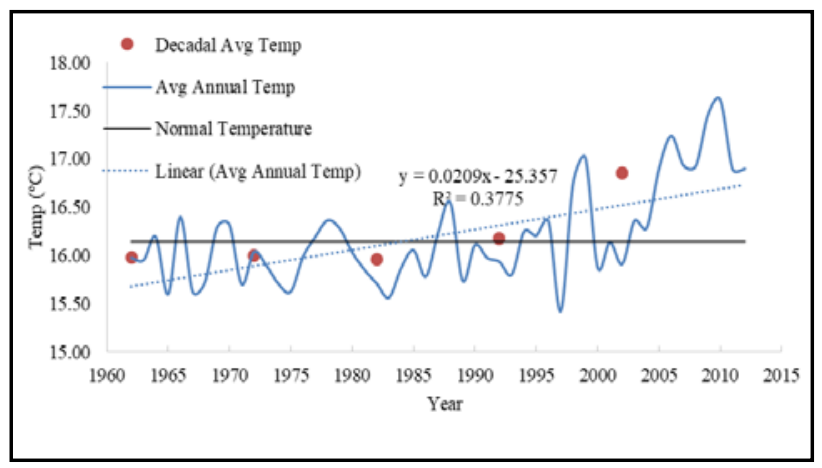

Figure 2. Inter annual and decadal variability of temperature in Taplejung station

A similar trend was observed for decadal average temperature where pre 1990 decades experienced temperature lower than the normal while post 1990 decades experienced temperature above the normal (Figure 2 indicated by dots). The trend can be observed more clearly in Figure 3 b. which shows a statistically significant warming trend $(p<0.001)$ and this is more pronounced in recent decades. The bandwidth of temperature change shows the trend of temperature for every 30 years. Figure 3 c. shows an increasing trend for the bandwidth of temperature change. The trend is statistically significant $(p<0.001)$ which is a strong evidence that the region is experiencing climate warming.

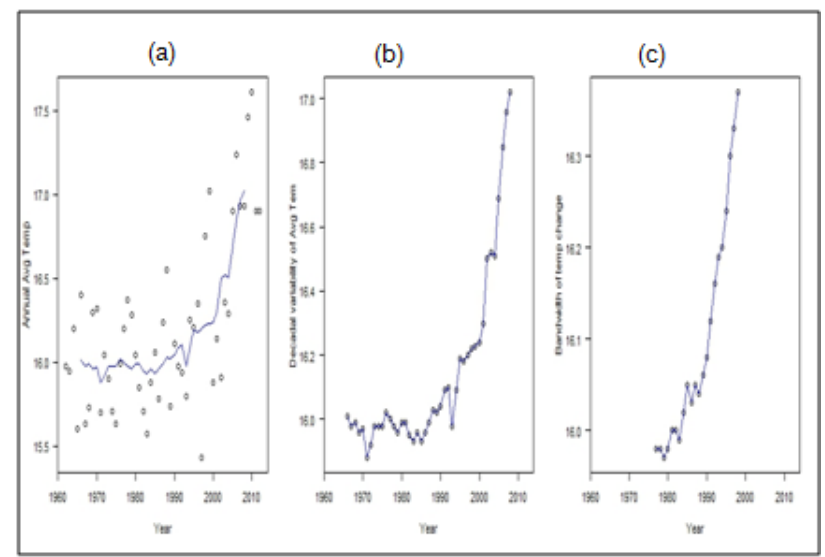

Figure 3. Trends of average annual temperature (a), decadal average temperature (b) and bandwidth of temperature change 
The inter-annual and decadal variability of precipitation can be observed in Figure 4. The normal rainfall was found to be $1981.4 \mathrm{~mm}$. Erratic pattern of annual rainfall is observed with frequent fluctuations below and above the normal. Between 1948 and 2014, there were an equal number of dry and surplus years. The lowest rainfall was observed to be $1408.9 \mathrm{~mm}$ in the year 2009 and highest rainfall was observed to be $2505 \mathrm{~mm}$ in the year 2003 .

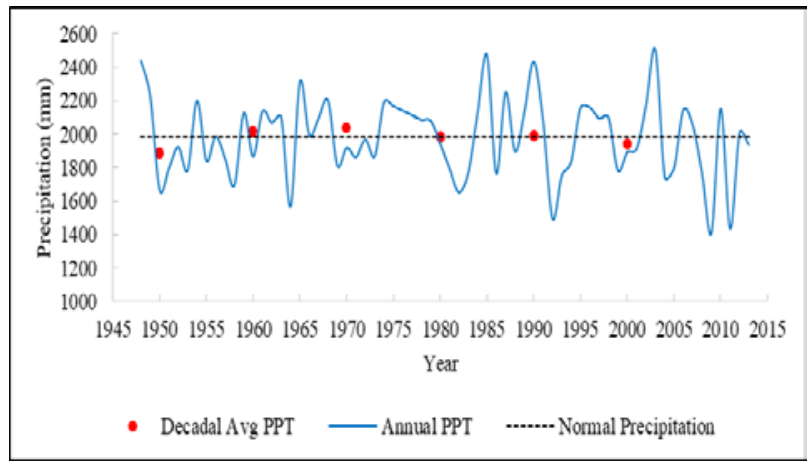

Figure 4. Inter-annual and decadal variability of precipitation

Unlike annual precipitation, decadal average precipitation was found to be less fluctuating above and below the normal precipitation. Time series of annual precipitation (Figure 5 a) shows precipitation, somewhat like increasing till 1975 and then decreasing but not statistically significant as suggested by Man Kendall test. The decadal average precipitation and bandwidth of precipitation change also didn't show any significant trend (Figure 5).

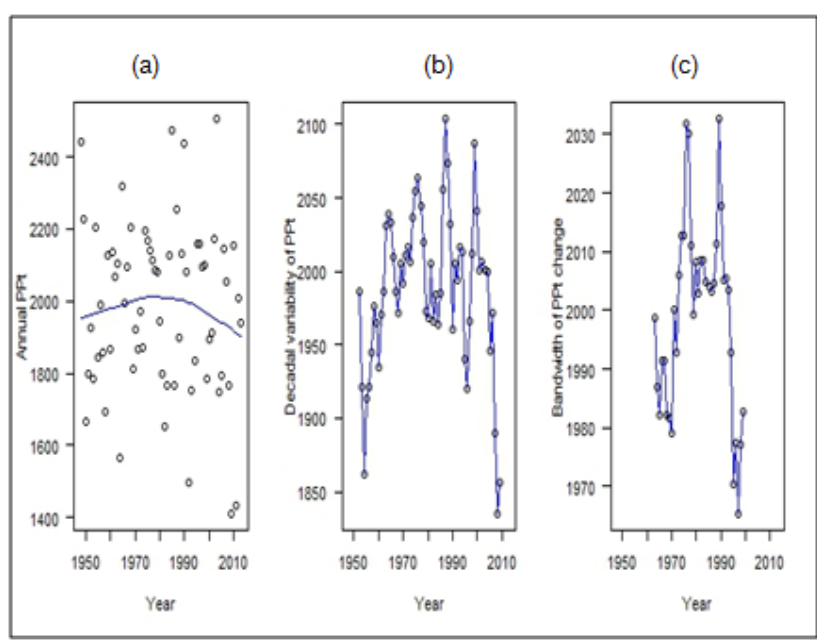

Figure 5. Trends of annual precipitation (a), decadal average precipitation (b) and bandwidth of precipitation change (c)

\subsection{Dendrochronological Analysis and Growth Response}

Tree ring analysis of Larix griffithii (Lindl. et Gord.) Hort ex Carr, a subalpine deciduous conifer from the study site showed distinct rings, with clear demarcation of early wood and late wood cells and have characters suitable for dendroclimatic studies. Based on the ring-width analysis, three ring-width site chronologies of Larix griffithii was prepared. The site chronology of the region extended to 1745-2015 (Figure 6).

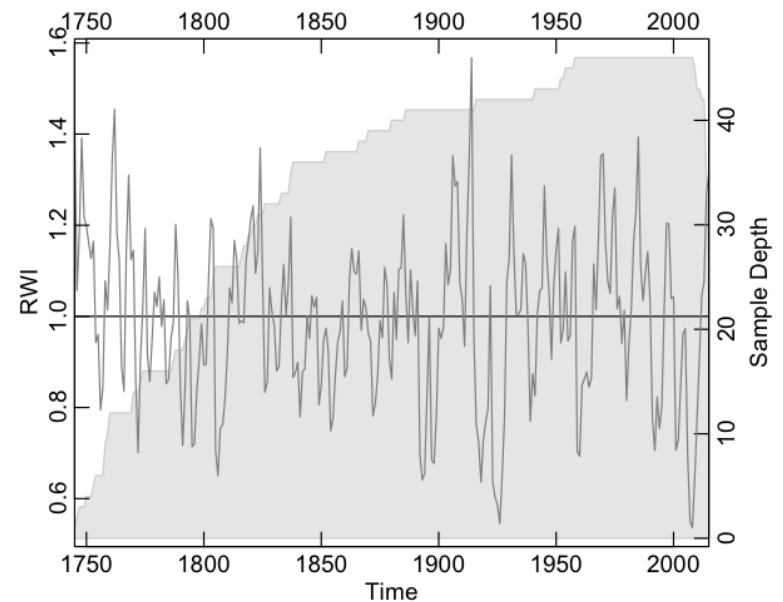

Figure 6. Tree ring-width residual site chronologies of Larix griffithii from Kanchenjunga Conservation Area

The site chronology was developed using 56 tree cores from the study area. Mean sensitivity was found to be 0.19 . Signal to noise ratio was 13.7 with expressed population of signals of 0.93 (Table 1 ).

Table 1. Dendrochronological Statistics of Larix griffithii in the Study Site

\begin{tabular}{|l|c|}
\hline Variables & Kanchenjunga \\
\hline No. of trees (cores) & $28(56)$ \\
\hline Chronology length & $271(1745-2015)$ \\
\hline Mean ring width measurement (mm) & 1.10 \\
\hline Mean sensitivity (MS) & 0.19 \\
\hline Standard deviation (SD) & 0.69 \\
\hline Series inter-correlation (Rbar) & 0.50 \\
\hline Autocorrelation (AR1) & 0.68 \\
\hline Signal-to-noise ratio (SNR) & 13.7 \\
\hline Expressed Population Signals (EPS) & 0.93 \\
\hline
\end{tabular}

Correlation (Pearson's correlation) between the radial growth (Ring width standard chronology) of Larix griffithii with monthly climate data in Nepal Himalaya show variations in climatic response patterns. There was a negative relationship between the radial growth of Larix griffithii in the study area and monthly mean temperature in all the months. Very highly significant negative correlation was observed during the previous and current summer seasons especially in the June, July, August, September of previous year and July, August and September of the current year $(p<0.001)$. The strongest negative correlation was observed for the July temperature in both previous year and current year. The negative correlation was also significant for the months of post monsoon seasons mainly September and November $(p<$ 0.05) as shown in Figure 7. On analyzing the relationship between monthly precipitation and standard ring width chronology of the site, significant positive correlation was found for both previous year and current year July precipitation $(p<0.05)$. This indicates that warm temperatures without sufficient precipitation during summer season lead to moisture stress and limit the growth. 


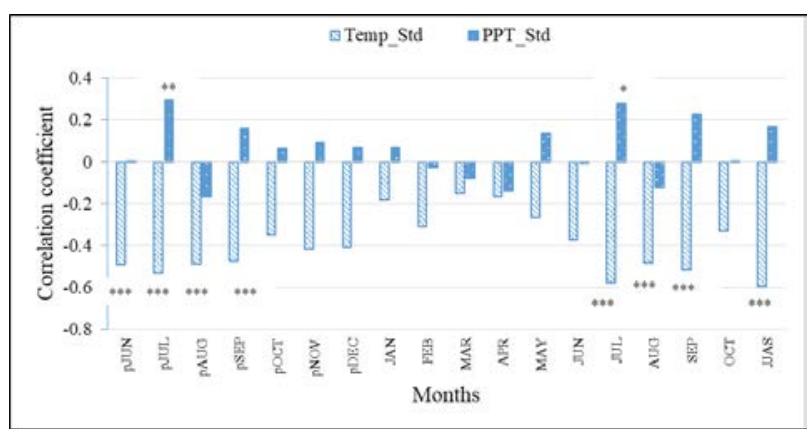

Figure 7. Correlation between the radial growths (standard chronology) of Larix griffithii in Kanchenjunga with monthly climate data in Nepal Himalaya (* statistically significant at $p<0.05$; ** statistically significant at $p<0.01 ; \quad * * *$ statistically significant at $p<0.01$ )

\subsection{Long-term Variability from the reconstructed Data}

From the growth-climate response analysis from $\mathrm{KCA}$, it was found that temperature reconstruction of June-September (JJAS) period is theoretically possible. The chronology statistics also strongly indicate the potential for climatic reconstruction $(E P S>0.85)$ as shown in Figure 8. Hence, the transfer function explained by [15] was applied for the temperature reconstruction of June-September months in eastern Nepal. These models were subjected to the $F$ test of significance using the entire temperature records available for 1948-2013 AD. It was found that the temperature transfer functions were highly significant at $1 \%$ level of significance. The reconstruction was also subjected for rigorous validation test.

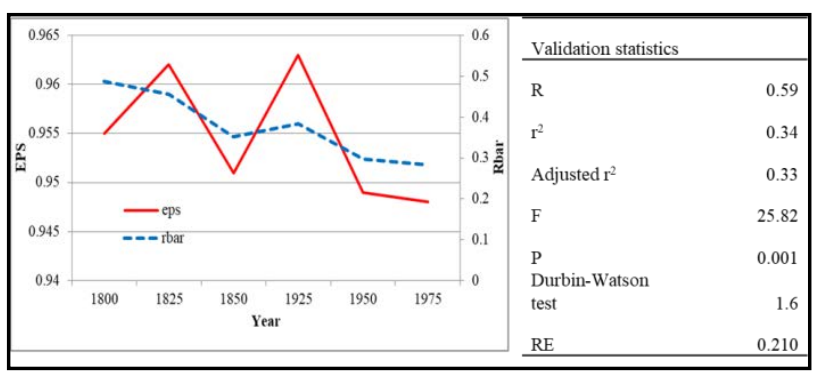

Figure 8. EPS and Rbar for the chronology and leave-one-out-validation statistics of the reconstruction model of the JJAS average temperature in Kanchenjunga Conservation Area

Based on the ring width index of the Larix griffithii from KCA area, temperature of the summer months (June-September, JJAS) for the period of 1770-2015 AD was reconstructed (Figure 9).

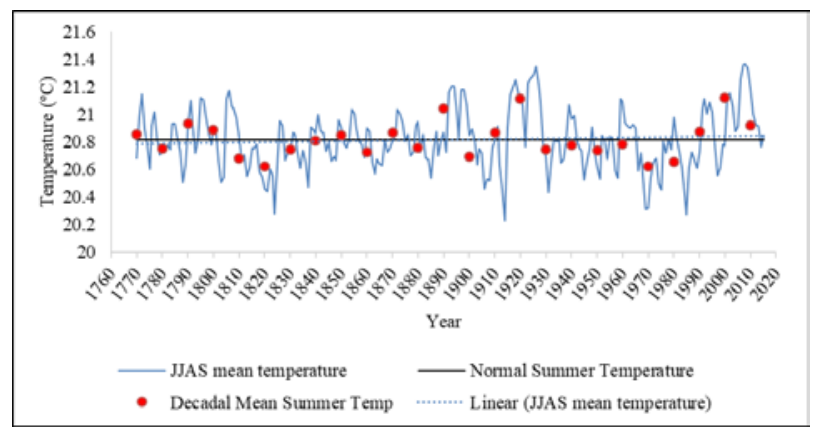

Figure 9. Inter-annual and decadal variability of mean summer temperature (Reconstructed)
The reconstruction passed the validation test based on leave-one-out cross-validation test (Figure 8). The reconstructed normal summer temperature was found to be $20.82^{\circ} \mathrm{C}$. This reconstruction captures the $34 \%$ variability in the temperature in the region. Between 1770 and 2015, summer temperature was found to fluctuate at a maximum of $0.55^{\circ} \mathrm{C}$ above the normal summer temperature in the year 2008 and a maximum $0.59^{\circ} \mathrm{C}$ below the normal summer temperature in the year 1914 indicating that within this time period, 2008 had the warmest summer and 1914 had the coolest summer. The time series of annual mean summer temperature shows a very slight increasing trend (Figure 10 a.), however the increase is not statistically significant.

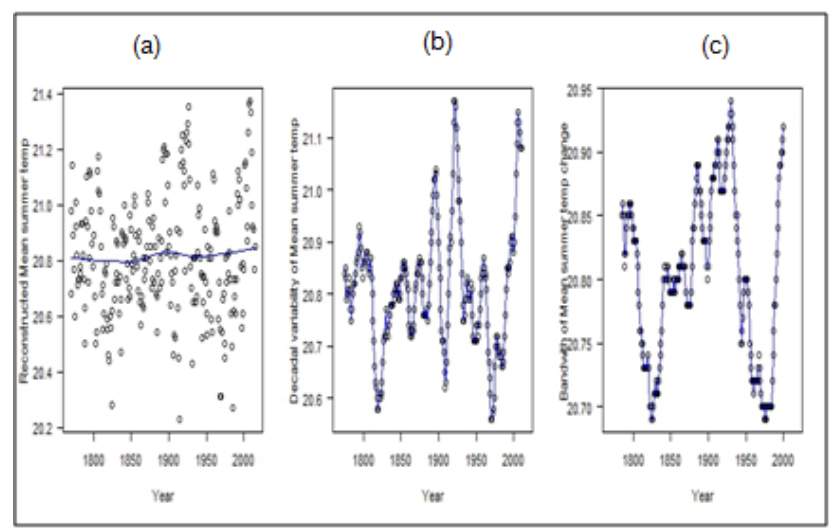

Figure 10. Trends of mean summer temperature (a), decadal mean summer temperature (b) and bandwidth of mean summer temperature change (c)

The decadal mean summer temperature is shown by the dots in Figure 10. The reconstructed temperature shows several warm and cool periods. The short cold episodes were observed around 1810s, 1910s, and 1970s while worm periods were observed around 1890s, 1920s and 2000s (Figure $10 \mathrm{~b}$ ). The temperature in the region is increasing after 1930s, more pronounced after 1970s (Figure 9). However overall significant increasing or decreasing trend cannot be observed in both the decadal mean summer temperature and bandwidth of mean summer temperature change (Figure 10, b, and c). The bandwidth of summer temperature is observed to have a sharp decline in the first half of $19^{\text {th }}$ century followed by a slow increase until the first quarter of $20^{\text {th }}$ century and then declining gradually until 1970s followed by a sharp increase in the first decade of $21^{\text {st }}$ century.

\section{Discussion}

The normal temperature for KCA as suggested by the Taplejung station was found to be $16.15^{\circ} \mathrm{C}$. A statistically significant warming trend of $0.021^{\circ} \mathrm{C}$ year ${ }^{-1}$ was observed. This trend is consistent with the average annual temperature trend in Nepal which is $+0.025^{\circ} \mathrm{C}_{\text {year }}^{-1}$ [29]. However this trend is lower than that of other studies carried out in high mountain of Nepal. An analysis of the time series of temperature and precipitation reconstructed from seven stations located between 2660 and 5600 masl. in Khumbu region shows that the mean temperature

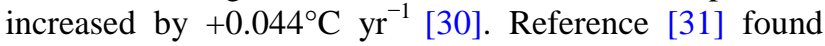


that the warming was consistent and continuous after the mid-1970's and average warming in annual temperature between 1977 and 2000 was found to be $0.06^{\circ} \mathrm{C} \mathrm{yr}^{-1}$ while a study by Practical Action Nepal over based on data from 1976 - 2005 shows maximum temperature was found to be increasing at a greater rate $\left(0.05^{\circ} \mathrm{C} /\right.$ year $)$ than the minimum temperature $\left(0.03^{\circ} \mathrm{C} /\right.$ year $)$ [32]. The lower trend in our study could be attributed to the consideration of relatively long length (1962- 2012) of temperature record. Reference [33] studied the extreme temperature and precipitation pattern over Nepal. Decreasing trend in the cool days and cold nights increasing trend in the warm nights have been identified. Between 1960 and 2012, the warmest year on record was 2010 and post 1990s decades are getting warmer than pre 1990s decades. Abrupt change in temperature anomaly can be observed after 1997 with sharp increase in temperature in recent years. This observation is also evident in the Cumulative Sum chart (CUSUM) given by [34]. Increasing trend of decadal average temperature and significant increasing trend in band width of temperature has been supported by almost all climate change research in Nepal.

Study of DHM shows an overall positive trend in annual precipitation in eastern development region [29]. However, no any significant trend in annual precipitation is found in our study. In contrast to the study of [29], our observation is consistent with findings reported by [33], which shows that most of the stations above $1500 \mathrm{~m}$ elevation do not show clear trends in annual precipitation. The study on precipitation variability by [31] for 19481994 also supports our result as their findings show significant variability on annual and decadal time scales but did not find distinct long-term trends in precipitation records. The normal rainfall was found to be $1981.4 \mathrm{~mm}$. This value is slightly higher than the mean annual precipitation of Nepal. Mean annual precipitation of stations varies from less than $150 \mathrm{~mm}$ to above $5000 \mathrm{~mm}$ in Nepal [29].

The reconstructed JJAS temperature for KCA shows several warm and cool episodes along with a recent warming trend. This reconstruction, compared with other temperature reconstructions from Nepal viz. FebruaryJune [35], March-September [36] and March-May [37], Bhutan Himalaya [38] and East Asia [39] did not perfectly match with these and other reconstructions. However, some common signals have been captured or shared. A recent warming trend has been observed in Picea smithiana tree ring based reconstruction of March-May temperature [37], Abies spectabilis ring based reconstruction of March-September temperature in western Nepal Himalaya [36] and Picea spinulosa temperature reconstruction from Bhutan [38]. However, all Nepal February-June temperature reconstruction using tree rings chronologies of multiple species has revealed a cooling trend in last decades of the $20^{\text {th }}$ century but October-February temperature reconstruction revealed a warming trend in recent decades [35]. Other regional studies have also reported an increase in the summer temperature during recent decades [40].

Growth of a tree is associated with several biotic and abiotic factors including climate $[15,41]$. The radial growth of Larix fluctuated over time with changing climate and constant increment or decrement in the growth was not observed. Warm temperatures without sufficient precipitation during summer season leads moisture stress and limit the growth in the study area. A few studies on Pinus wallichiana, Cedrus deodara, and Picea smithiana from high-altitude forests and tree lines in India [42,43] and in some conifer species from Tibet and adjacent mountain regions have shown growth enhancement during recent decades $[44,45,46]$. Negative correlation with the temperature in most of the months is not a common response. However, in dry inner valleys of the Nepal Himalaya, cool and moist year favour the growth of the conifers [35] and board leaf species Betula Utilis [47].

None of the studies from the Nepal Himalaya is reported in the Larix griffithii in terms of growth climatic response and very few studies have been carried out from the eastern Himalaya of India [48,49]. A study in the moist site of Arunachal Pradesh, Eastern India Himalaya, found a higher growth in relation to increased temperature during November of the previous growth year and May and July of the current growth year, whereas current January temperature had a negative relationship with tree growth [48]. For precipitation, August and September of the previous year and July of the current year have an inverse relationship, whereas January and February of the current year exhibit a direct relationship with growth [48]. The response from Indian Himalaya [48] and in the present study is slightly different, which might be due to variation in site condition, climate and difference in the influence of monsoon system. The negative relationship, observed in the present study, with the pre-monsoon and monsoon season temperature indicated towards some threshold temperature or moisture stress because the increase in temperature in pre-monsoon and monsoon season without adequate rainfall increases the evapotranspiration leading to a soil-moisture deficit and limiting tree growth [27].

The response observed between the growth and temperature during summer months and seasons in the study area is also observed in the growth-climate relationship of the many conifers from the dry sites of the Nepal Himalaya [10,35,50] and in western Indian Himalaya [51]. The positive relation with winter precipitation indicates that, higher winter precipitation may become favourable for tree growth by maintaining enough soil moisture for the rapid growth of trees during spring and early summer, before the commencement of monsoon rains [48]. From an analysis, in the growthclimate response of different tree species it seems that, in the Himalaya, the growth-response trees to climate change and variability is spatiotemporally different and not unidirectional [10,36,48,50,52].

\section{Conclusion}

Climate change in the form of significant warming trend is evident in the eastern region of Nepal while significant increasing or decreasing trend of precipitation is not observed. Shift in the temperature regime is observed after 1997 in the region. Compared to the annual precipitation, the temperature was found to exhibit greater variability form the normal. Larix griffithi with clear demarcation of early wood and late wood cell possess the 
potential for dendroclimatic studies. Thus a site chronology extending 1745- 2015 was prepared and summer temperature was reconstructed for 1770 -2015. From the analysis of climatic variability, species regeneration and dendroclimatic responses, it is concluded that the species will experience the overall range shift mostly due to temperature stress and moisture limitations in the eastern Nepal. The summer temperature coupled with precipitation is seen to limit the tree growth through moisture limitations. With the temperature in increasing trend, it is likely that the growth of Larix will face heat stress. Owing to the information gap of Larix sp. in terms of demography, climate sensitivity and localities in other areas, this study forms basis for further studies to assess climatic responses from other areas too. Such studies incorporating other proxy evidence like pollen from lake sediments could enhance our understanding of the spatiotemporal response of vegetation in association with climate variability and change.

\section{Acknowledgements}

We would like to thank Department of Environment, MoE and National Academy of Science and Technology (NAST) for the research grant. We would like to acknowledge Narayan Gaire for his support in Lab work at NAST. The authors also thanks Department of Hydrology and Meteorology government of Nepal for providing climate datasets and anonymous reviewers for their constructive comments.

\section{References}

[1] Shrestha, A., \& Aryal, R., "Climate change in Nepal and its impact on Himalayan glaciers," Regional Environmental Change, 11, S65-S77, 2011.

[2] Khatiwada, K. R., Panthi, J., Shrestha, M. L., \& Nepal, S. "Hydro-climatic variability in the Karnali River Basin of Nepal Himalaya,” Climate, 4(17), 1-14, 2016.

[3] Shrestha, A., Wake, C., Dibb, J., \& Mayewski, P., "Precipitation fluctuations in the Nepal Himalaya and its vicinity and relationship with some large-scale climatological parameters," International Journal of Climatology, 20, 317-327, 2000.

[4] MoE, National Adaptation Programme of Action (NAPA) to Climate Change, Ministry of Environment, Kathmandu, Nepal, 2010.

[5] Lama, S., \& Devkota, B., "Vulnerability of mountain communities to climate change and adaptation strategies," The Journal of Agriculture and Environment, 10, 65-71, 2009.

[6] Aryal, U., Adhikari, T. R., Thakuri, S., \& Rakhal, B., "Flood hazard assessment in Dhobi-Khola Watershed Kathmandu, Nepal using hydrological model," International Research Journal of Environmental Science, 5(11), 21-33, 2016.

[7] Huq, S., A. Rahman, M. Konate, Y. Sokona, \& H. Reid., Mainstreaming adaptation to climate change in least developed countries (LDCs). In International Institute for Environment and Development, London, 2003.

[8] Brown, P.M., "Climate effects on fire regimes and tree recruitment in Black Hills Ponderosa pine forests,” Ecology, 87, 2500-2510, 2006.

[9] Brown, P.M., \& R. Wu., "Climate and disturbance forcing of episodic tree recruitment in a Southwestern ponderosa pine landscape,” Ecology, 86, 3030-3038, 2005.

[10] Gaire, N. P., Koirala, M., Bhuju, D. R., \& Borgaonkar, H. P., "Treeline dynamics with climate change at the central Nepal Himalaya,” Climate of the Past, 10(4), 1277-1290, 2014.
[11] Wei, X.-X., \& Wang, XQ, "Recolonization and radiation in Larix (Pinaceae): evidence from nuclear ribosomal DNA paralogues," Molecular Ecology 13, 3115-3123, 2004.

[12] Christian, T., Rushforth, K., \& Luscombe, D, Larix potaninii var. himalaica. The IUCN Red List of Threatened Species. Version Mar. 2013

[13] Camp, A.E., "Age structure and species composition changes resulting from altered disturbance regimes on the Eastern Slopes of the Cascades range, Washington," Journal of Sustainable Forestry, 9, 39-67, 1999.

[14] Carpenter, C., Ghimire, S., \& Brown, T., Report on the flora and fauna of the Kanchenjunga region, WWF Nepal Program Report Series, 1994.

[15] Fritts, H.C, Tree rings and climate, The Blackburn Press, New Jersey, 1976.

[16] Mudelsee, M., Climate time series analysis, Springer, 2013.

[17] WMO, Guide to climatological practices. 2011 Edition, Secretariat of the World Meteorological Organization, 2011

[18] Rinn, F., TSAP-Win Reference Manual. Version 0.53. Heidelberg, 1996.

[19] Rinn, F., TSAP-Win: time series analysis and presentation for dendrochronology and related applications, Version 0.55, User reference. Heidelberg, Germany, 2003. Available at: http://www.rimatech.comSalzer

[20] Holmes, R.L., "Computer-assisted quality control in tree-ring dating and measurement,” Tree-Ring Bulletin, 43, 69-78, 1983.

[21] Grissino-Mayer, H.D., "Evaluating cross-dating accuracy: a manual and tutorial for the computer program COFECHA", TreeRing Research, 57, 205-221, 2001.

[22] Cook, E.R., A time series analysis approach to tree-ring standardization. In The University of Arizona, 1985.

[23] Schulman, E., "Tree rings and runoff in the south plate river basin," Tree-Ring Bulletin, 11, 18-24, 1945.

[24] Cook, E.R., \& Peters, K., “The smoothing spline: a new approach to standardizing forest interior tree-ring width series for dendroclimatic studies,” Tree-Ring Bulletin, 41, 45-53, 1981.

[25] Briffa, K. R., Jones, P. D., Schweingruber, F. H., Shiyatov, S. G., \& Cook, E. R., "Unusual twentieth-century summer warmth in a 1,000-year temperature record from Siberia,” Nature, 376(6536), 156, 1995.

[26] Wigley, T.M.L., Briffa, K.R., \& Jones, P.D., “On the average value of correlated time series with applications in dendroclimatology and hydrometeorology," Journal of Climate and Applied Meteorology, 23, 201-213, 1984.

[27] Fritts, H.C., Tree Rings and Climate, Cambridge University Press, Cambridge, 1976, p567.

[28] Cook, E.R., \& L.A. Kairiukstis, Methods of dendrochronology: applications in the environmental sciences, Kluwer Academic Publishers, the Netherlands, 1990.

[29] DHM, Study of climate and climatic variation over Nepal, Department of Hydrology and Meteorology, Kathmandu, 2015.

[30] Salerno, F., Guyennon, N., Thukuri, S., Viviano, G., Romano, E., Vuillermoz, E., Tartari, G., "Weak precipitation, warm winters and springs impact glaciers of south slopes of Mt. Everest (Central Himalaya) in the last 2 decades (1994 - 2013),” The Cryosphere, 9 1229-1247, 2015.

[31] Shrestha, A. B., Wake, C. P., Mayewski, P. A., \& Dibb, J. E., "Maximum temperature trends in the Himalaya and its vicinity: an analysis based on temperature records from Nepal for the period 1971 - 94,” Journal of Climate, 12, 2775-2786, 1999.

[32] PAN, the Temporal and spatial variability of climate change over Nepal (1976-2005). Practical Action Nepal, Kathmandu, 2009.

[33] Baidya, S. K., Shrestha, M. L., \& Sheikh, M. M., "Trends in daily climatic extremes of temperature and precipitation in Nepal”, Journal of Hydrology and Meteorology, 5(1), 38-51, 2008.

[34] Kattel, D. B., \& Yao, T. "Recent temperature trends at mountain stations on the southern slope of the central Himalayas," Journal of Earth System Science, 122(1), 215-227, 2013.

[35] Cook, E.R., Krusic, PJ, \& Jones, PD., "Dendroclimatic signals in long tree- ring chronologies from the Himalayas of Nepal," International Journal of Climatology, 23, 707-732, 2003.

[36] Sano, M., Furuta, F., Kobayashi, O. \& Sweda, T., “Temperature variations since the mid-18th century for western Nepal, as reconstructed from tree-ring width and density of Abies spectabilis”, Dendrochronologia, 23, 83-92, 2005. 
[37] Thapa, U.K., Shah, S.K., Gaire, N.P., \& Bhuju, D.R., "Spring temperatures in the far-western Nepal Himalaya since AD 1640 reconstructed from Picea smithiana tree-ring widths," Climate Dynamics, 2014.

[38] Krusic, P.J., Cook, E.R., Dukpa, D., Putnam, A.E., Rupper, S., \& Schaefer, J., "Six hundred thirty-eight years of summer temperature variability over the Bhutanese Himalaya," Geophysical Research Letters, 42, 2988-2994, 2015.

[39] Cook, E. R., Krusic, P. J., Anchukaitis, K. J., Buckley, B. M., Nakatsuka, T., \& Sano, M., "Tree-ring reconstructed summer temperature anomalies for temperate East Asia since 800 CE,” Climate Dynamics, 41(11-12), 2957-2972, 2013.

[40] Shi, F., Ge, Q., Yang, B., Li, J., Yang, F., Ljungqvist, F.C., Solomina, O., Nakatsuka, T., Wang, N., Zhao, S., Xu, C., Fang, K., Sano, M., Chu, G., Fan, Z., Gaire, N.P., \& Zafar, M.U., “A multiproxy reconstruction of spatial and temporal variation in Asian summer temperature over the last millennium,” Climatic Change, 2015.

[41] Speer, J.H., Fundamentals of tree ring research, The University of Arizona Press, Tucson, 2010.

[42] Borgaonkar, H.P., Ram, S., \& Sikder, A.B., “Assessment of tree ring analysis of high-elevation Cedrus deodara D. Don from western Himalaya (India) in relation to climate and glacier fluctuations,” Dendrochronologia, 27, 59-69, 2009.

[43] Borgaonkar, H.P., Sikder, A.B., \& Ram, S., "High altitude forest sensitivity to the recent warming: a tree-ring analysis of conifers from western Himalaya, India,” Quaternary International, 236, 158-166, 2011.

[44] Gou, X., Chen, F., Jacoby, G.C., Cook, E.R., Yang, M., Peng. J., \& Zhang, Y., "Rapid tree growth with respect to the last 400 years in response to climate warming, northeastern Tibetan Plateau," International Journal of Climatology, 27, 1497-1503, 2007.

[45] Liang, E.Y., Shao, X.M., \& Xu, Y., "Tree-ring evidence of recent abnormal warming on the southeast Tibetan Plateau," Theoretical and Applied Climatology, 98, 9-18, 2009.

[46] Liang, E.Y., Wang, Y., Xu, Y., Liu, B., \& Shao, X., "Growth variations of Abies georgei var. smithii along altitudinal gradients in the Sygera Mts., south eastern Tibetan Plateau," Trees, 24, 363-373, 2010.

[47] Dawadi, B., Liang E.Y., Lide T., Yao T., \& Devkota L.P., "Premonsoon precipitation signal in tree rings of timberline Betulautilis in the central Himalayas," Quaternary International 283:72-77, 2013.

[48] Chaudhary, V., \& Bhattacharya, A., "Tree ring analysis of Larix griffithiana from the Eastern Himalayas in the reconstruction of past temperature,” Current Science-Bangalore, 79(12), 1712-1715, 2000.

[49] Shah, S. K. and A. Bhattacharyya \& V. Chaudhary, "Stream flow reconstruction of Eastern Himalaya River, Lachen 'Chhu', North Sikkim, based on tree ring data of Larix griffithiina from Zemu Glacier basin,” Dendrochronologia, 32: 97-106, 2014.

[50] Kharal, D.K., Meilby, H., Rayamajhi, S., Bhuju, D. \& Thapa, U.K., "Tree ring variability and climate response of Abies spectabilis along an elevation gradient in Mustang, Nepal,” Banko Janakari, 24(1), 3-13, 2014.

[51] Yadav, RR, "Tree ring imprints of long-term changes in climate in western Himalaya, India,” Journal of Biosciences, 34(5), 699-707, 2009.

[52] Liang, E.Y., Dawadi, B., Pederson, N., \& Eckstein, D., "Is the growth of birch at the upper timberline in the Himalayas limited by moisture or by temperature?” Ecology, 95, 2453-2465, 2014. 